\title{
Author Correction: A mixed antagonistic/ synergistic miRNA repression model enables accurate predictions of multi-input miRNA sensor activity
}

Jeremy J. Gam¹,2, Jonathan Babb ${ }^{1,2} \&$ Ron Weiss ${ }^{1,2}$

Correction to: Nature Communications https://doi.org/10.1038/s41467-018-04575-0, published online 22 June 2018

In the originally published version of this Article, financial support was not fully acknowledged. The PDF and HTML versions of the Article have now been corrected to include support from the National Science Foundation (NSF), award number 1745645.

Published online: 02 November 2018

(c) (i) Open Access This article is licensed under a Creative Commons Attribution 4.0 International License, which permits use, sharing, adaptation, distribution and ceproduction in any medium or format, as long as you give appropriate credit to the original author(s) and the source, provide a link to the Creative Commons license, and indicate if changes were made. The images or other third party material in this article are included in the article's Creative Commons license, unless indicated otherwise in a credit line to the material. If material is not included in the article's Creative Commons license and your intended use is not permitted by statutory regulation or exceeds the permitted use, you will need to obtain permission directly from the copyright holder. To view a copy of this license, visit http://creativecommons.org/licenses/by/4.0/.

(c) The Author(s) 2018

\footnotetext{
${ }^{1}$ Department of Biological Engineering, Massachusetts Institute of Technology (MIT), Cambridge, MA 02139, USA. ${ }^{2}$ Synthetic Biology Center, MIT, Cambridge, MA 02139, USA. Correspondence and requests for materials should be addressed to R.W. (email: rweiss@mit.edu)
} 